\title{
Phenotyping of soft spring wheat varieties to expand the genetic diversity of cultivars resistant to biotic factors
}

\author{
Aparina V.A. ${ }^{1,2 *}$, Boyko N.I. ${ }^{2}$, Morozova E.V. ${ }^{2}$, Sukhomlinov V.Yu. ${ }^{2}$, Piskarev V.V. ${ }^{2}$ \\ ${ }^{1}$ Novosibirsk State Agrarian University, Novosibirsk, Russia \\ ${ }^{2}$ Siberian Research Institute of Plant Production and Breeding - Branch of the Institute of Cytology and \\ Genetics, SB RAS, Novosibirsk, Russia \\ *email: aparinava@bionet.nsc.ru
}

\begin{abstract}
N.I. Vavilov wrote that the introduction of immune varieties into the culture or their creation by selection is the most radical instrument of protection against various diseases caused by parasitic fungi, bacteria, viruses. The effectiveness of using resistant wheat cultivars is high at present, especially when the resistance of the cultivar to diseases is harmonized with other agronomic characteristics. The study of 70 collection varieties of soft spring wheat (Triticum aestivum L.) of the mid-late maturity group was carried out in 2018-2019. Suitable weather conditions for the development and manifestation of the studied phytopathogens were in the years of study. The high natural spread of powdery mildew observed in 2019, which allowed us to assess the reaction of varieties in different degrees of resistance. The weather in August was favorable for the formation of the high thousand grain weight of the studied cultivars. In 2019, the thousand grain weight (the average values for the group in $2018-38.3 \mathrm{~g}$ and $2019-39.5 \mathrm{~g})$ and the yield $(286.6$ and $473.5 \mathrm{~g} / \mathrm{m}^{2}$ ) of the studied varieties were higher than in 2018 . Twenty varieties that are resistant to powdery mildew (Blumeria graminis), leaf (Puccinia triticina) and stem (Puccinia graminis) rust to varying degrees and have productivity characteristics (thousand grain weight and yield) at the level of the Sibirskaya 17 (standard) were characterized as sources of resistance to biotic factors: Obskaya 2, Ekada 6, Pyramida, Pamyati Ryuba, Riks, Rh 24, Chernozemnouralskaya, Ekada 113, Yugo-Vostochnaya 4, Tulaykovskaya 5, Margarita, Lutescens 505, Omskaya 38, Weawer, Tulaykovskaya 108, RL 345, Mertsana, Voevoda, Tulaykovskaya 10, Ekada 85. The resistance of varieties to pathogens was determined mainly by such genes as: $\operatorname{Lr} 9, \operatorname{Lr} 19, \operatorname{Lr} 24, \operatorname{Lr} 26$; $S r 25$; PmBel, PmAg.i.1, PmAg.i.2, Pm38.
\end{abstract}

Acknowledgments: This work was supported by RFBR, project number 20-016-00093. 